\title{
GERAKAN INTELEKTUAL KAJIAN JARINGAN ISLAM LIBERAL
}

\author{
Oleh : \\ Zainol Hasan \\ Fakultas Ekonomi dan Bisnis Islam IAI Ibrahimy Situbondo \\ hasans_ideas@yahoo.com
}

\begin{abstract}
The term Liberal Islam Network was not well known and was not noticed by people in Indonesia. Moreover, the number of proponents' is very small, can be counted on the fingers. It presents a new face of Islam which is in the form of non-orthodox, Islam that has compatibility with alteration of era and Islam that has an insight into the future. That is not Islam that has ignorance into the future or that is not outdated. But the ideas promoted by them get a strong reaction from the public, either from the Indonesian religious leaders, or from the Indonesian Moslem intellectuals. Therefore, the term Liberal Islam Network was actually popularized by the opponents.
\end{abstract}

Key words: Liberal, Islam Network and Framing Theory

\section{A. Pendahuluan}

Kehidupan manusia pada dasarnya dibangun atas interaksi diantara mereka. Dunia ini dibangun dari kelompok-kelompok yang berbeda. Dalam interaksi, orang menggunakan simbol-simbol untuk memaknai prilaku sesuai dengan penafsiran masing-masing. Jadi dalam hal ini, makna sebuah prilaku bukan terletak pada bahasa tetapi makna tersebut dibangun dari hasil interaksi dangan lawan bicara. Kemunculan teori interaksi simbolik didasarkan pada asumsi tersebut. Adapun asumsi lainnya mengatakan bahwa individu akan merespon suatu sistem simbolik termasuk objek sosial dan objek fisik berdasarkan makna yang dikandungnya. Namun respon tersebut tidak dipengaruhi oleh faktor eksternal, tetapi lebih pada bagaimana individu tersebut mendefinisikan situasi yang dihadapi dalam interaksi sosialnya. Kemampuan manusia untuk menciptakan simbol membuktikan bahwa manusia telah mempunyai kebudayaan yang tinggi dalam berkomunikasi dengan orang lain.

Liberalisme dimaknai sebagai simbol "kebebasan". Simbol ini mencampurkan, membandingkan, dan menganalogikan tanda dan objek yang diacu dalam sistem politik liberal. Misalnya tentang kebebasan 
berbicara akan dianalogikan dengan kebebasan berijtihad, ${ }^{1}$ setiap individu atau kebebasan melakukan penafsiran terhadap teks. Fundamentalis Islam dianggap sebagai suatu sistem otoriter yang berlawanan dengan liberalisme. Prinsip kebebasan juga menyimbolkan pembebasan dari belenggu teks yang sebelumnya dipahami secara dogmatis. ${ }^{2}$

Dengan kata lain JIL tujuan gerakannya adalah untuk melawan atau menghamabat gerakan Islam fundamendalis, yg telah menghambat cara berfikir orang Islam ditengah peradaban jaman yang selalu berubah. Pada prinsipnya, pemikiran Islam Liberal sangat kontras dengan apa yang menjadi pandangan Islam yang selama ini dipahami oleh masyarakat. Maka dari sinilah penulis mengkaji gerakan Jaringan Islam Liberal (JIL) untuk mengetahui bagaimana gagasan-gagasan yang diusung oleh Jaringan Islam Liberal serta upaya-upaya yang ditempuh untuk menyebarluaskan pandangannya.

\section{B. Pembahasan}

\section{Munculnya Islam Liberalisme}

Masalah Islam dan tuntutan zaman adalah persoalan yang penting pada saat ini, mengingat banyak orang memandang Islam sebagai agama yang hanya mendasarkan kepada religious-dogmatis sehingga tertinggal oleh peradaban. ${ }^{3}$ Sekelompok cendikiawan muslim dengan jumlah yang

1 Kata ijtihad pertama kali dipakai dalam hadist Nabi saw. dan sejak itulah menyebar dikalangan muslimin. Kata ini tidak dijumpai dalam Al-qur'an, sedangkan kata yang dijumpai dan semakna dengannya dalam Al-qur'an adalah tafaqquh. Al-qur'an mengajak secara terbuka untuk melakukan 'pendalaman dan penelahaan' terhadap agama. Dimasa akhir kenabian ini, ijtihad atau tafaqquh merupakan tugas amat penting dan tanggung jawab yang harus dilakukan, karena ia merupakan syarat bagi keabadian Islam. Ijtihad dapat disebut sebagai "kekuatan penggerak Islam". Ibnu Sina seorang filosof Islam merefleksikan masalah ini dengan cerdas. Menurutnya, "Prinsip-prinsip umum Islam bersipat tetap dan tidak berubah; sementara peristiwa dan persoalan terus berubah. Setiap zaman memiliki tuntunan dan permasalahan sendiri. Oleh karenanya, disetiap era dan zaman diperlukan adanya sekelompok ulama yang menghususkan diri dan mendalami prinsip-prinsip Islam dan permasalahan zaman, kemudian melakukan ijtihad dan menarik kesimpulan hukum berdasarkan prinsip-prinsip Islam tersebut terhadap persoalan-pesoalan baru. Lebih jelasnya Lihat. Murtadha Muthahhari \& Imam Al-Ghazali, Agar Kita Tidak Sesat; Prinsip-prinsip Akidah Wahyu dan Penutup Kenabian, (Bandung : Pustaka Hidayah, 2008), hlm. 337-338.

2 Suciati, Mempertemukan Jaringan Islam liberal (JIL) Dengan Majelis Tarjih PP Muhammadiyah, (Yogyakarta : CV. Arti Bumi Intaran, 2006), hlm. 25-26.

${ }^{3}$ Yang dimaksud peradaban (civilization) adalah masyarakat yang teramat mapan dalam segala hal, baik dalam kehidupan keagamaan, politik, administrasi, pendidikan, ilmu pengetahuan, dan lain sebagainya. Untuk lebih jelasnya Lihat. Samsul Munir Amin, 
masih bisa dihitung, mulai mengadakan kajian-kajian Islam setidaknya untuk dua masalah penting yang menuntut pemecahan dengan segera; Pertama, mengetahui secara benar ajaran Islam murni sebagai wujud dari filsafat sosial, keyakinan ketuhanan. Kedua, untuk mengenal dan mengetahui kondisi dan tuntutan zaman.

Akhir-akhir ini muncul pemikiran Islam baru yang menamakan dirinya Islam Liberal ${ }^{4}$ menjadi sebuah wacana yang sangat menarik untuk dikaji. Hal ini terjadi kerena Islam Liberal yang dikembangkan pertama kalinya oleh Charles Kurzman mendapat reaksi hebat dari masyarakat, entah tokoh agama, ataupun para intelektual muslim.

Sepintas bagi kalangan tertentu, penyebaran Islam Liberal mungkin mudah diasosiasikan sebagai wacana yang cenderung kebarat-baratan. Dengan demikian mudah mendatangkan kecurigaan, jenis pemikiran ini bisa berakibat buruk terhadap kelangsungan otentitas ajaran Islam. Kesan negatif ini wajar muncul karena istilah Liberal terutama dengan konteks kehidupan agama terlanjur dipahami pejorative (merendahkan,

Sejarah Peradaban Islam, (Jakarta; Amzah, 2010), hlm. 7-8.

${ }^{4}$ Awalnya Islam Liberal (liberal Islam) mengidentifikasikan dirinya secara kontras dengan tradisi "Islam adat" dan Islam Revivalis". Islam Liberal berusaha menghadirkan kembali Islam di masa lalu sesuai dengan kepentingan modernitas. Kritik Islam Liberal atas tradisi "Islam Adat" maupun Islam Revivalis adalah bahwa pandangan kaum Islam Adat dan kaum Revivalis yang melihat Islam masa lalu sebagai keterbelakangan, sedangkan Islam Liberal melihat Islam masa lalu jika dipahami secara benar, Islam akan sesuai dengan perkembangan. Pendek kata, Islam Liberal merupakan pendukung modernitas, yakni memberikan penghargaan atas gerakan modernitas, sehingga kadang Islam Liberal disebut Islamic Modernism. Lihat. Qodir Zuly, Syariah Demokrat; pemberlakuan Islam di Indonesia, (Yogyakarta: Pustaka Pelajar, 2004), hlm. 75-76. Sedangkan di Indonesia, Setelah Nurcholish Madjid meluncurkan gagasan sekularisasi dan ide-ide teologi inklusif-pluralis dengan Paramadinahnya, kini kader-kader Nurcholish Madjid mengemabangkan gagasannya lebih intensif lewat yang mereka sebut "Jaringan Islam Liberal" yang mereka singkat dengan JIL ini, mulai aktif pada bulan maret 2001 lalu. Kegiatan awal dilakukan dengan menggelar kelompok diskusi maya (milis) yang tergabung dalam islamlib@yahoogroups. com selain menyebarkan gagasannya lewat website www.islamlib.com Jaringan Islam liberal (JIL) mengakui bahwa pemikiran Islam liberal sebagaimana yang telah diusungnya, bukan murni hasil pemikiran mereka. sebenarnya pemikiran yang bercorak liberal ini sudah muncul pada era antara 70-an dan 80 -an. Mereka mengakui bahwa pemikiran yang progresif adalah positif bagi perkembangan masyarakat, sehingga perlu diwadahi dalam suatu organisasi, seperti JIL. Melalui wadah ini, siapapun yang bisa menjadi konttributor bagi pengembangan pemikiran ini akan mendapatkan tempat. Dengan demikian, ide pemikiran akan dapat berkembang secara sehat untuk didiskusikan dan disebarkan kepada masyarakat. Organisasi ini diharapkan bisa melakukan counter opinion terhadap klaim agama Islam yang kaku dan membelenggu umat. 
memburukkan). Misalnya ada yang memahami istilah Liberal sebagai cara pandang kalangan agnostik yang ragu terhadap kebenaran agama. ${ }^{5}$

Di Indonesia kemudian dikembangkan oleh kelompok intelektual muslim melalui organisasi Jaringan Islam Liberal (JIL). munculnya reaksi dari berbagai kelompok masyarakat mengakibatkan munculnya identifikasi JIL terhadap 'kelompok oposisi' Islam Liberal yang mereka sebut dengan Islam Fundamentalis ${ }^{6}$. Kalau meminjam istilah Abdurrahaman Wahid, makna JIL tentang Fudamentalisme Islam kurang lebih adalah golongan yang menekankan secara harfiah makna kitab suci Al-qur'an dan hadist Nabi. Golongan ini dianggap melakukan pemaknaan terhadap Al-qur'an secara literal (teks) bukan secara kontekstual. ${ }^{7}$ Islam Liberal pada dasarnya adalah rejuvenasi dari gerakan kebangkitan Islam yang di mulai sejak awal abad ke-19 hampir seluruh dunia Islam. Istilah "Liberal" sendiri berarti "pembebasan" yang pada tataran wacana bermakna ganda. Pada satu sisi, ia berarti pembebasan kaum muslimin dari kolonialisme yang pada saat itu menguasai hampir seluruh dunia Islam. Sedangkan disisi lain, bermakna pembebasan kaum muslimin dari cara-cara berfikir dan berprilaku keberagaman yang menghambat kemajuan.

Selama periode pembebasan itu, muncullah tokoh-tokoh intelektual muslim seperti Ziya Gokalp dan Kamal Ataturk di Turki, Muhammad Abduh dan Ali Abd Al-Raziq Mesir, Ahmad Khan dan Muhammad Iqbal di India, Fazlur Rahman Pakistan, serta Muhammad Natsir, dan Nurcholis Madjid di Indonesia.

Ada satu benang merah yang bisa ditarik dari para intelektual muslim liberal. Yakni perasaan dan semangat untuk membebaskan (liberating) umat Islam dari belenggu keterbelakangan dan kejumudan sejak-paling tidak-lima abad terakhir. Belenggu inilah yang dianggap sebagai sebab utama ketakberdayaan bangsa-bangsa muslim di depan bangsa asing (kolonialisme). Hanya dengan membangun kembali cara

5 Arifin Syamsul, Islam Indonesia : Sinergi Membangun Civil Islam dalam Bingkai Keadaban Demokrasi, (Malang : UMM Press, 2003), hlm. 177- 178.

${ }^{6}$ Istilah Fundamentalisme di Barat pada awalnya diletakkan pada gerakan nonkompromis yang dilakukan oleh sekelompok Protestan di Amerika pada akhir abad ke 19 dan awal abad ke 20 dengan tujuan untuk mengembalikan ajaran-ajaran Kristen pada sumber-sumber fundamental melalui pemahaman literal atas injil yang diyakini sebagai yang paling otentik (murni) lihat. Hangs Kung dan Jurgen Moltmann, "Preface", di Hangs Kung and Jurgen Moltman (eds.), Fundamentalisme as an Ecumenical Challenge, (London: SCM Press, 1992), hlm. 7.

7 Ibid, hlm. 1-2. 
pandang dan sikap keberagamaan mereka, kondisi menyedihkan itu dapat diperbaiki.

\section{Studi Gerakan Sosial}

Dalam studi gerakan sosial mekanisme framing dipergunakan oleh para akademisi gerakan sosial dalam studi gerakan sosial. Para akademisi mengakui pentingnya proses framing dalam memahami sukses dan gagalnya sebuah gerakan sosial. Sebagaimana Snow dan Banford mencatat, sukses tidaknya gerakan sosial terletak pada sejauh mana memenangkan pertempuran atas arti. Hal ini berkaitan dengan upaya para pelaku perubahan mempengaruhi makna dalam kebijaksanaan publik. Oleh karena itu, pelaku perubahan memiliki tugas penting mencapai perjuangannya melalui membuat framing masalah-masalah sosial dan ketidakadilan. Ini sebuah cara untuk meyakinkan kelompok sasaran yang beragam dan luas sehingga mereka terdorong mendesakkan sebuah perubahan. Sebagaimana Snow dan Benford, lebih lanjut menekankan dua komponen penting dalam memframing sebuah gerakan, yaitu, diaknosis elemen atau mendefinisikan masalah dan sumbernya dan memprediksi elemen sekaligus mengidentifikasi strategi yang tepat untuk memperjuangkan masalah tersebut.

Zald, lebih lanjut, mengidentifikasikan beberapa topi penting yang tidak hanya berhubungan dengan proses framing tetapi juga memainkan peran penting dalam membentuk framing. Dengan kata lain topik-topik ini menjadi sumber dasar framing. Pertama adalah kontradiksi budaya dan alur sejarah. Zald berpendapat bahwa kesempatan politik dan mobilisasi, seringkali tercipta melalui ketegangan budaya dan kontradiksi yang berlangsung lama muncul menjadi bahan proses framing seperti, keluhan dan ketidakadilan, sehingga aksi kolektif bisa terjadi. Kontradiksi budaya juga membuat penyebab mobilisasi ketika dua atau lebih tema-tema budaya yang memiliki potensi kontradiksi dibawa kedalam kontradiksi aktif melalui kekuatan aksi kolektif. Kemungkinan lain misalnya, ketika realitas pelaku kelompok masyarakat dilihat secara substansi memiliki perbedaan dari justifikasi ideologi sebuah gerakan sosial. ${ }^{8}$

Semua Gerakan sosial pastinya membutuhkan alat untuk menjalankan framing, dan yang paling menonjol adalah media. Melalui media massa, baik yang mereka miliki sendiri maupun media massa umum, mereka mempromosikan frame mereka dalam mendefiniskan

8 Situmorang Abdul Wahid, Gerakan Sosial : Studi Kasus Beberapa Perlawanan, (Yogyakarta: Pustaka Pelajar, 2007), hlm. 10-11. 
berbagai macam problem sosial. Namun media massa biasanya mempuyai frame tersendiri. ${ }^{9}$ Misalnya ketika media yang mengadopsi isu lingkungan akan berbeda dari media yang tidak memiliki ketika mereka menurunkan laporan tentang bencana lingkungan. Karenanya, framing isu di dalam media menjadi bagian penting di dalam proses keseluruhan proses framing, karena tidak hanya karena media memiliki agenda tersendiri tetapi karena setiap orang memiliki interpretasi berbeda dalam sesuatu hal.

McCarthy dan Zald memiliki gagasan serupa mengenai framing dalam media. Mereka menekankan bahwa media adalah target utama bagi upaya proses framing dalam gerakan sosial. Akan tetapi, media tidaklah satu-satunya. Upaya-upaya langsung mempengaruhi pemerintah, pemilihan umum dan agenda publik juga bagian utama gerakan sosial. Gerakan sosial melebur dalam taktik yang langsung atau tidak langsung menargetkan persepsi dan prilaku kelompok sasaran dengan mengkomunukasikan framing gerakan. Agen-agen gerakan berupaya membawa isu mereka kedalam kelompok sasaran yang beragam, seperti media, partai politik, pejabat parlemen dan pemerintah. ${ }^{10}$

\section{Misi Utama Jaringan Islam liberal}

Pertama, mengembangkan penafsiran-penafsiran Islam yang liberal sesuai dengan prinsip-prinsip yang dianuat, serta menyebarkan kepada khalayak seluas mungkin.

Kedua, mengusahakan ruang-ruang dialog yang terbuka dan bebas dari tekanan konservatisme. Dengan demikian perkembangan pemikiran dan aksi Islam bisa berlangsung dengan sehat.

Ketiga, Mengupayakan terciptanya struktur sosial dan politik yang adil dan manusiawi. Sistem demokrasi dipercayai sebagai salah satu sistem yang saat ini dapat memenuhi kebutuhan masyarakat Indonesia. ${ }^{11}$

\section{Agenda Islam Liberal}

Sejak agenda Islam yang dimulai lebih dari seabad silam, berbagai persoalan yang menyangkut kehidupan kaum muslim telah didiskusikan. Paling tidak, ada empat agenda utama yang menjadi payung bagi persoalan-persoalan yang dibahas oleh para pembaru dan intelektual

${ }^{9}$ Ichwan Moch Nur, Model Tripartite Teori Gerakan Sosial : Mobilisasi Sumberdaya, Kesempatan Politik dan Framing, 2010, hlm. 26.

${ }^{10}$ Ibid, hlm. 13.

11 Assyaukanie Luthfi, Islam Benar Versus Islam Salah, (Jakarta : Kata Kita, 2007), $61-62$

48 JURNAL LISAN AL-HAL 
muslim selama ini. Empat agenda tersebut adalah; politik, toleransi agama, emansipasi perempuan dan kebebasan berekspresi. Kaum muslim di tuntut melihat keempat agenda tersebut dari perspektif dari mereka sendiri, bukan dari perspektif masa silam yang lebih banyak memunculkan kontradiksi ketimbang penyelesaian yang baik.

Pertama, adalah agenda politik, yang dimaksud adalah sikap politik kaum muslimin dalam melihat sistem pemerintahan yang berlaku. Secara teologis, persoalan ini boleh dibilang sudah selesai, khususnya setelah para intelektual muslim, semacam Ali Abd al-Raziq, Ahmad Khalafah (Mesir), Muhammad Taleqani (Iran) dan Nurcholis Madjid (Indonesia), menganggap persoalan tersebut sebagai persoalan ijtihadi yang diserahkan sepenuhnya kepada kaum muslimin. Pilihan terhadap bentuk negara-apakah republik, kerajaan, semi-kerajaan, parlementer, atau apapun namanya adalah pilihan manusia, bukan pilihan Tuhan. ${ }^{12}$

Kedua, menyangkut kehidupan antaragama kaum muslim. Dengan makin majemuknya kehidupan bermasyarkat di negara-negara muslim, pencarian teologi pluralisme tampaknya menjadi sesuatu yang tak bisa ditawar. Pengalaman awal masyarakat Madinah yang di pimpin Nabi kerap dijadikan model percontohan, adanya toleransi kehidupan antar umat beragama dalam Islam. Dengan model ini, Islam dianggap sebagai agama yang menghormati keberadaan agama-agama lain, inklusif dan toleran. ${ }^{13}$

Ketiga, emansipasi perempuan, mengajak kaum muslim untuk memikirkan kembali beberapa doktrin agama yang cenderung merugikan dan mendeskriditkan kaum perempuan. Hal ini karena doktrin-doktrin

12 Sebagaimana yang disabdakan oleh Nabi: "antum a'lamu bi umuri dunyakum" (Kalian lebih tahu tentang urusan dunia kalian). Umat Islam lebih mengetahui urusan dunia mereka. Karena urusan politik adalah urusan dunia, maka menjadi hak kaum muslim untuk mengetahuinya sendiri. Tak ada satu ayatpun di dalam Al-qur'an yang mewajibkan mereka menentukan satu bentuk atau sistem politik tertentu. Allah hanya mengisyaratkan perlunya memiliki tatanan yang jujur dan adil. Dalam hal ini politik, bisa apa saja, termasuk demokrasi yang kini dianggap sebagai alternatif terbaik dari sistem politik yang pernah ada.

${ }^{13}$ Al-qur'an pun telah menjamin; Sesungguhnya orang-orang mukmin, orang-orang Yahudi, orang-orang Nasrani dan orang-orang Shabiin, siapa saja diantara mereka yang benar-benar beriman kepada Allah, hari kemudian dan beramal saleh, mereka akan menerima pahala dari Tuhan mereka, tidak ada kehawatiran terhadap mereka, dan tidak (pula) mereka bersedih hati. Al-Baqarah, ayat 62 dan dalam ayat yang lain menjelaskan; Sesungguhnya orang-orang mukmin, orang-orang Yahudi, Shabiin dan orang-orang Nasrani, siapa saja (diantara mereka) yang benar-benar beriman kepada Allah, hari kemudian dan beramal saleh, maka tidak ada kehawatiran terhadap mereka dan tidak (pula) mereka bersedih hati. Al-Maaidah: 69. 
tersebut dari manapun sumbernya-bertentangan dengan semangat dasar Islam yang mengakui persamaan dan menghormati hak-hak semua jenis kelamin. ${ }^{14}$

Keempat, kebebasan berpendapat, ini menjadi penting dalam kehidupan kaum muslim modern, khususnya ketika persoalan ini berkaitan erat dengan masalah hak-hak asasi manusia (HAM). Islam sudah pasti sangat menghormat HAM, dan dengan demikian, juga menghormati kebebasan berpendapat. Sejak dibukanya kembali "pintu ijtihad" lebih dari satu abad silam, tak ada alasan bagi seorang muslim untuk takut memiliki pendapat pribadi. Pendapat (ijtihad) adalah sesuatu yang sangat dihargai dan dihormati dalam Islam. Begitu dihormatinya sebuah pendapat, sebuah kaidah fiqih menegaskan bahwa seseorang akan diberikan dua pahala jika benar dalam berijtihad, dan diberikan satu pahala jika salah dalam berijtihad. ${ }^{15}$

\section{Pengelolaan Jaringan Islam Liberal}

Pengelolaan JIL dikomandani oleh beberapa pemikir muda, diantaranya; seperti Luthfi Assyaukani (Universitas Paramadina Mulya), Ulil Abshar Abdallah dan Ahmad Sahal (Jurnal Kalam) dll. Markas JIL yang berpusat di JL Utan Kayu No. 68-H Matraman Jakarta timur ini, sering dijadikan tempat diskusi atau ngobrol-ngobrol dari para aktivis muda dari beberapa kalangan. JIL juga bekerja sama dengan para intelektual, penulis dan akademisi dalam dan luar negeri untuk menjadikan kontributornya. Mereka diantaranya; Nurcholish Madjid (almarhum), Azyumardi Azra, Masdar F. Mas'ud, Komaruddin Hidayat dan lain sebagainya. Sedangkan yang dari luar negeri : Charles Kurzman University of north Carolina, Abdallah Laroui Muhammad V University Maroko, Mohammed Arkoun University of Sorbonne Prancis, Djohan Effendi Deakin University Australia,

\footnotetext{
${ }^{14}$ Sesungguhnya laki-laki dan perempuan yang muslim, laki-laki dan perempuan yang mukmin, laki-laki dan perempuan yang tetap dalam ketaatannya, laki-laki dan perempuan yang benar, laki-laki dan perempuan yang sabar,laki-laki dan perempuan yang khusuk, laki-laki dan perempuan yang bersedekah , laki-laki dan perempuan yang berpuasa, laki-laki dan perempuan yang memelihara kehormatannya, laki-laki dan perempuan yang banyak menyebut (nama) Allah, allah telah menyediakan untuk mereka ampunan dan pahala yang besar. Al-Ahzab : 35. Hai manusia, sesungguhnya kami menciptakan kamu dari seorang laki-laki dan seorang perempuan dan menjadikan kamu berbangsa-bangsa dan bersuku-suku supaya kamu saling kenal mengenal. Sesungguhnya orang yang paling mulia diantara kamu di sisi Allah ialah orang yang paling bertakwa diantara kamu. Sesungguhnya Allah maha mengetahui lagi maha mengenal. Al-Hujurat : 13.

${ }^{15}$ Ibid., hlm. 72-75.
} 
Ihsan Ali-Fauzi Ohio University Amerika Serikat dan lain sebagainya. ${ }^{16}$

\section{Kegiatan yang Dilaksankan JIL}

Pertama, sindikasi penulis Islam Liberal. Maksudnya adalah mengumpulkan tulisan sejumlah penulis yang selama ini dikenal (atau belum dikenal) oleh publik luas sebagai pembela pluralisme dan inklusivisme. Sindikasi ini menyediakan bahan-bahan tulisan, wawancara dan artikel yang baik untuk koran-koran di daerah yang mengalami kesulitan mendapatkan penulis yang baik. Dengan adanya "otonomi daerah", maka peran media lokal makin penting, dan suara-suara keagamaan yang toleran penting untuk disebarkan melalui media daerah ini. Setiap minggu, disediakan artikel dan wawancara untuk koran-koran daerah.

Kedua, talk show di kantor berita radio 68 H. Talk show ini mengundang sejumlah tokoh yang selama ini dikenal sebagai "pendekar pluralisme dan inklusivisme" untuk berbicara tentang berbagai isu sosialkeagamaan di tanah air. Acara ini diselenggarakan setiap minggu, dan disiarkan melaui jaringan radio namlapanha di 40 radio, antara lain; radio namlapanha Jakarta, radio smart Menado, radio DMS Maluku, radio unisi Yogyakarta, Radio PTPN Solo, radio mara Bandung dan radio prima FM Aceh.

Ketiga, penerbitan buku. JIL menghadirkan buku-buku yang bertemakan pluralisme dan inklusivisme agama, baik berupa terjemahan, kumpulan tulisan, maupun penerbitan ulang buku-buku lama yang masih relevan dengan tema-tema tersebut. JIL sudah menerbitkan buku kumpulan artikel, wawancara, dan diskusi yang diselenggarakan oleh JIL, berjudul Wajah Liberal Islam di Indonesia.

Keempat, penerbitan buku saku. Untuk kebutuhan pembaca umum, JIL menerbitkan buku saku setebal 50-100 halaman dengan bahasa renyah dan mudah dicerna. Buku saku ini mengulas dan menanggapi sejumlah isu yang menjadi bahan perdebatan dalam masyarakat. Tentu, tanggapan ini dari perspektif Islam Liberal. Tema-tema itu antara lain : jihad, penerapan syariat Islam, penerapan ajaran amar ma'ruf nahi mungkar konsep tentang pembangunan 'tempat ibdah' dan sebagainya.

Kelima, website islamlib.com. Program ini berawal dari dibukanya milis Islam Liberal islamliberal@yahoogroups.com yang mendapat respon positif. Ada usulan dari beberapa anggota untuk meluaskan milis ini ke

16 Nuim Hidayat \& Adian Husaini, Islam Liberal : Sejarah, Konsepsi, Penyimpangan dan jawabannya, (Jakarta : Gema Insani, 2002), hlm. 5. 
dalam bentuk website yang bisa diakses oleh semua kalangan. Sementara milis tetap dipertahankan untuk kalangan terbatas saja. Semua produk JIL (sindikasi media, talk show radio, dll.) dimuat dalam website ini. Website ini juga memuat setiap perkembangan berita, artikel, atau apapun yang berkaitan dengan misi JIL.

Keenam, iklan layanan masyarakat. Untuk menyebarkan visi Islam Liberal, JIL memproduksi sejumlah iklan layanan masyarakat (Public Service Advertisement) dengan tema-tema seputar pluralisme, penghargaan atas perbedaan, dan pencegahan konflik sosial. Salah satu iklan yang diproduksi adalah iklan berjudul "Islam Warna-Warni".

Ketuju, diskusi keislaman. Kerjasama dengan pihak luar (universitas, LSM, kelompok mahasiswa, pesantren, dan pihak-pihak lain), JIL menyelenggarakan sejumlah diskusi dan seminar mengenai tema-tema keislaman dan keagamaan secara umum. Termasuk dalam kegiatan ini adalah diskusi keliling yang diadakan melalui kerjasama dengan kelompok-kelompok mahasiswa di sejumlah universitas, seperti Universitas Indonesia Jakarta, Universitas Diponegoro Semarang, Institut Pertanian Bogor, UIN Syarif Hidayatullah Jakarta, dll. ${ }^{17}$

\section{Wacana yang diusung oleh JIL}

Pertama, penafsiran Islam yang non-literal, substansial, kontekstual dan sesuai dengan denyut nadi peradaban manusia yang sedang dan terus berubah. Kedua, penafsiran Islam yang dapat memisahkan mana unsurunsur didalamnya yang merupakan kreasi budaya setempat, dan mana yang merupakan nilai fundamental. Kita harus bisa membedakan mana ajaran dalam Islam yang merupakan pengaruh kultur Arab dan mana yang tidak. Islam kontekstual dalam pengertian nilai-nilainya yang universal harus diterjemahkan dalam konteks tertentu, misalnya konteks Arab, Melayu, Asia Tenggara, dan seterusnya. Tetapi, bentuk Islam yang kontekstual itu hanya ekspresi budaya dan kita tidak diwajibkan untuk mengikutinya. Misalnya dalam konteks Arab; Jilbab, potong tangan, qishash, rajam, jenggot, jubah, tidak wajib diikuti, karena itu hanya ekspresi lokal partikular Islam di Arab. Yang harus diikuti adalah nilainilai universal yang melandasi praktik-praktik itu. Jilbab intinya adalah mengenakan pakaian yang memenuhi standar kepantasan umum (public decency). Kepantasan umum tentunya sifafnya fleksibel dan berkembang sesuai dengan kebudayaan manusia.

17 www. islamlib.com, Senin, Tgl 6 Dec 2010. 07.00 WIB. Lihat Suciati, Mempertemukan Jaringan Islam Liberal..... Ibid, hlm. 53-54.

52 
Ketiga, umat Islam hendaknya tidak memandang dirinya sebagai "masyarakat" atau "umat" yang terpisah dari golongan yang lain. Umat manusia adalah keluarga universal yang dipersatukan oleh kemanusiaan itu sendiri. Kemanusiaan adalah nilai yang sejalan, bukan berlawanan dengan Islam. Larangan kawin beda agama, dalam hal ini antara perempuan Islam dengan laki-laki non-muslim, sudah tidak relepan lagi.

Keempat, kita membutuhkan struktur sosial yang dengan jelas memisahkan mana kekuasaan politik dan mana kekuasaan agama. Agama adalah urusan pribadi, sementara pengaturan kehidupan publik adalah sepenuhnya hasil kesepakatan masyarakat melalui prosedur demokrasi. Nilai-nilai universal agama tentu diharapkan untuk membentuk nilai-nilai publik, tetapi doktrin dan praktik peribadatan agama yang sifatnya partikular adalah urusan-urusan masing-masing agama. ${ }^{18}$

\section{Reaksi Terhadap Jaringan Islam Liberal}

Perkembangan pemikiran Islam Liberal menimbulkan reaksi pro dan kotra. Bagi yang pro diantaranya, menurut Hamid Basyaib, berpandangan :

Pertama, ajaran Islam, harus terus menerus ditafsirkan, sesuai dengan perkembangan masyarakat diberbagai tempat dan masa. Keharusan ini muncul, karena manusia niscaya menghadapai aneka masalah dengan segala karakteristik masalah-masalah tersebut, baik yang timbul dari nalurinya untuk menghindari keburukan yang mungkin menimpanya maupun justru guna mengajar kebaikan demi kelangsungan dan kesejahteraan hidupnya, secara pribadi maupun kelompok. Jangankan untuk masa modern dan ditempat lain (Indonesia), di masa hidup Nabi Muhammad dan di dunia Arab sendiri, penyesuaian itu harus dan memang telah dilakukan sejak era Islam awal. Petuah Nabi kepada Mu'adz Bin Jabal ketika orang ini menjabat Gubenur di Yaman, suatu wilayah Arab yang bagaimanapun punya nuansa karakter yang bisa berbeda dari Mekkah atau Madinah. Ia diminta berijtihad ketika tidak menemukan petunjuk dari Al-qur'an dan Hadist. Yang penting semua cara-cara kreatif hasil ijtihad itu harus berorentasi pada kemaslahatan masyarakat. Seraya berteguh pada prinsip yang amat dimuliakan dalam Islam yaitu keadilan. Dalam konteks legislasi, ini berarti yang diutamakan adalah cita-cita moralnya, bukan legeslasi spesifik atau formulasi literalnya.

Kedua, ancaman serius bagi setiap pemikiran keagamaan adalah

18 Dzulmanni (ed), Islam liberal \& Fundamental: Sebuah Pertarungan Wacana, (Yogyakarta : Elsaq Press, 2007), hlm. 8-9. 
kemandekan, kebutuhan dan ketiadaan semangat inovasi. Kondisi semacam itu akan menyebabkan agama kehilangan relevansinya dengan zaman dan masyarakat yang terus berubah. Pemikiran keagamaan dalam bentuk tafsir, teologi, hukum-hukum fiqih, bagaimanapun merupakan hasil interaksi dengan semangat zamannya. Maka mandeknya pemikiran keagamaan akan berdampak langsung pada relevansi agama dan akhirnya peminggiran agama dari denyut nadi kehidupan manusia. Itulah sebabnya, di setiap kurun waktu harus selalu ada orang atau kelompok yang gelisah dan bisa menjawab tantangan zaman. ${ }^{19}$

Sedangkan yang kontra diantaranya, Hasan Bashar berpandangan: Pertama, Gagasan-gagasan yang dilontarkan oleh Jaringan Islam liberal (JIL), tidak bisa dianggap sebagai hal yang absah dalam koridor ihtilafiyah (perpedaan pendapat) yang memang sangat dikenal dalam lapangan pemikiran Islam. Akan tetapi gagasan-gagasan Jaringan Islam Liberal (JIL) telah memasuki wilayah Inhirafiyah (penyimpangan pendapat). Sebab gagasan-gagasan JIL bukan lagi terhadap Islam, melainkan terhadap sekularisme yang notabene berbasis Ideologi Kapitalis Barat.

Kedua, Dalam landasan pemikiran JIL membuka pintu ijtihad atau pembaharu pada dimensi Islam, artinya mereka dapat melakukan penafsiran berdasarkan logika atau nalarnya pada seluruh syariat Islam baik yang tertulis di Al-Qur'an maupun Al-Hadits. Mereka beranggapan bahwa penafsiran berdasakan logika pada teks-teks keislaman bisa membuat Islam bisa bertahan dalam segala cuaca. Ini tidak bisa dibenarkan, Sebagaimana menurut Ibnu Taimiyyah mengatakan: "akar kesesatan orang yang sesat adalah mendahulukan logikanya diatas nash yang diturunkan dari sisi Allah, dan cenderungannya kepada keinginan nafsu diatas prinsip mengikuti perintah Allah. tidak berlakunya lagi larangan pernikahan antara Muslim/ Muslimah dengan non-Muslim. Dan juga mengatakan Vodca (minuman beralkohol) boleh jadi di Rusia dihalalkan karena di sana udaranya sangat dingin. Sejatinya yang demikian tersebut merupakan pemikiran dan paham yang ingkar terhadap Alqur'an. ${ }^{20}$

\section{Simpulan}

Temuan-temuan besar dalam sejarah manusia bagian dari usaha

19 Ridlwan Nasir (ed), Dialektika Islam dengan Problem Kontemporer, (Surabaya : IAIN Press dan LKIS, 2006), hlm. 173-174. Lihat, Dzulmanni (ed), Islam liberal, Ibid... hlm. 40-41.

${ }^{20}$ Ibid, hlm. 173-175.

54 JURNAL LISAN AL-HAL 
menuju perbaikan mutu kehidupan adalah petunjuk Tuhan pula, karena temuan-temuan itu dilahirkan oleh akal manusia yang merupakan anugerah Tuhan. Karena itu seluruh karya cipta manusia, tidak peduli agamanya, tidak ada gunanya orang Islam membuat tembok ketat antara peradaban Islam dan peradaban Barat; yang satu dianggap unggul yang lain dianggap rendah. Apalagi sesama orang Islam. Setiap peradaban adalah hasil karya manusia dan milik semua bangsa.

Umat Islam harus mengembangkan suatu pemahaman bahwa suatu penafsiran Islam oleh golongan tertentu bukanlah paling benar dan mutlak. Meminjam istilah Ali Harb : tidak ada satupun school of thought yang berhak mengklaim dirinya sebagai satu-satunya kebenaran dan menafikan kebenaran lainnya. Karena itu harus ada kesediaan untuk menerima semua sumber kebenaran, termasuk yang datangnya dari luar Islam. Setiap golongan hendaknya menghargai hak golongan yang lain untuk menafsirkan Islam berdasarkan sudut pandangnya sendiri tetapi yang harus dilawan melainkan setiap usaha untuk memutlakkan pandangan keagamaan tertentu.

\section{DAFTAR PUSTAKA}

Abdul Wahid, Situmorang. Gerakan Sosial: Studi Kasus Beberapa Perlawanan. Yogyakarta. Pustaka Pelajar. 2007.

Al-qu'ran dan Terjemahnya, Departemen Agama RI. Jakarta. 1971.

Dzulmanni (ed). Islam liberal \& Fundamental: Sebuah Pertarungan Wacana, Yogyakarta. Elsaq Press. 2007.

Hidayat, Nuim \& Husaini, Adian. Islam Liberal: Sejarah, Konsepsi, Penyimpangan dan jawabannya. Jakarta. Gema Insani. 2002.

Kung, Hangs dan Moltmann, Jurgen. (eds.). Fundamentalisme as an Ecumenical Challenge. London. SCM Press. 1992.

Luthfi, Assyaukanie. Islam Benar Versus Islam Salah. Jakarta. Kata Kita. 2007.

Moch Nur, Ichwan. Model Tripartite Teori Gerakan Sosial: Mobilisasi Sumberdaya, Kesempatan Politik dan Framing, 2010. Makalah Belum Diterbitkan.

Muthahhari, Murtadha \& Al-Ghazali, Imam. Agar Kita Tidak Sesat; PrinsipPrinsip Akidah Wahyu dan Penutup Kenabian. Bandung. Pustaka Hidayah. 2008.

Nasir, Ridlwan (ed). Dialektika Islam dengan Problem Kontemporer. Surabaya. IAIN Press dan LKIS. 2006.

Samsul, Munir Amin. Sejarah Peradaban Islam. Jakarta. Amzah. 2010. 
Suciati, Mempertemukan Jaringan Islam liberal (JIL) Dengan Majelis Tarjih PP Muhammadiyah, Yogyakarta, CV. Arti Bumi Intaran. 2006.

Syamsul, Arifin. Islam Indonesia: Sinergi Membangun Civil Islam dalam Bingkai Keadaban Demokrasi. Malang. UMM Press. 2003.

www. islamlib.com.

Zuly, Qodir. Syariah Demokrat; Pemberlakuan Islam di Indonesia. Yogyakarta. Pustaka Pelajar. 2004. 